\title{
A Case of Schwannoma of the Nasal Septum
}

\author{
Seung Gon Jung, Soon Yong Han, Dong Eun Kim and Byung Hoon Ahn \\ Department of Otolaryngology-Head and Neck Surgery, Keimyung University College of Medicine, Daegu, Korea
}

비중격에 발생한 신경초종 1 예

정승곤 · 한순용 · 김동은 · 안병훈

계명대학교 의과대학 이비인후과학교실

\author{
Received May 2, 2010 \\ Revised June 21, 2010 \\ Accepted June 23, 2010 \\ Address for correspondence \\ Byung Hoon Ahn, MD \\ Department of Otolaryngology- \\ Head and Neck Surgery, \\ Keimyung University College of \\ Medicine, 216 Dalseong-ro, \\ Jung-gu, Daegu 700-712, Korea \\ Tel $+82-53-250-7718$ \\ Fax +82-53-256-0325 \\ E-mail bhahn@dsmc.or.kr
}

Schwannoma is a benign tumor originating from the peripheral nerve sheath that can arise on any myelinated nerve. A 32-year-old woman visited our clinic presenting with unilateral nasal obstruction. Based on the physical examination and CT scan, we initially diagnosed the disease as vascular origin tumor. Endoscopic excision was done after preoperative angiogram with embolization. Biopsy results revealed schwannoma originating from the nasal septum. Nasal septal schwannoma is extremely rare, and we herein report such a case with a review of literatures. Korean J Otorhinolaryngol-Head Neck Surg 2010;53:497-500

Key Words Nose neoplasms $\cdot$ Schwannoma $\cdot$ Nasal septum.

\section{서 론}

신경초종(schwannoma)은 말초 신경집(peripheral nerve sheath) 내 신경초 세포(schwann cell)에서 기원하는 양성 종양으로, 약 25 45\%가 두경부 영역에서 발생하며 주로 청신경에서 기원한다고 알려져 있다. ${ }^{1,2)}$ 신경초종은 신경초 세포가 있는 어떤 신경에서도 발생할 수 있지만, 비강 내 특히 비중격 내에 발생하는 경우는 극히 드물어 국내 문헌 보고는 아직까지 없다.

진단은 일반적으로 병력 및 증상, 방사선 검사를 통해 이 루어지며, 확진을 위해서는 특수면역염색을 통한 조직 검 사가 필수적이다.

치료는 종양의 완전한 외과적 적출이 원칙이며, 국소 재발 은 드문 편으로 알려져 있다. ${ }^{3)}$ 저자들은 32세 여성 환자의 좌측 비중격 내에서 발생한 신경초종 1 예를 치험하였기에 문헌고찰과 함께 보고하는 바이다.

\section{증 계}

32세 여자 환자가 수 년 전부터 좌측에 국한된 비폐색과
재채기, 비루가 있었고, 증상이 심할 때마다 개인 의원에서 알레르기성 비염에 준한 약물 치료를 받아왔으며, 내원 1 개월 전부터 증상이 더욱 심해지는 양상으로 본원 외래를 방문하였다.

비 내시경 검사상 좌측 비강의 상비도에 약 $3 \mathrm{~cm}$ 크기 의 용종상(polypoid) 종물이 관찰되었으며 미끈한 표면에 는 혈관상 분포를 띠고 있었다(Fig. 1).

부비동 전산화 단층 촬영 소견상 좌측 비강 및 사골동에 걸쳐 $36 \times 18 \mathrm{~mm}$ 크기의 종물이 관찰되었으며, 종물 내 에는 중등도의 불균등한 조영증강 소견이 관찰되었다(Fig. 2). 이학적 검사 및 영상학적 소견을 종합했을 때 일반적인 비강 내 폴립 및 상피성 종양 보다는 혈관성 종물을 의심하 여, 펀치 생검을 통한 조직 검사 보다는 술 전 혈관 조영술 을 통한 색전술을 시행한 후 비내시경하 종물 절제술을 계 획하였다.

수술 1 일 전 시행한 혈관 조영술상 좌측 비강의 접형구개 동맥이 지배하는 고혈관성 종물이 관찰되었고, 접형구개 동 맥의 분지에 색전술을 시행하였다. 색전술 후 종물에는 더 이상 조영증강되는 소견은 관찰되지 않았다.

전신 마취하에 비내시경하 종물 절제술을 시행하였으며, 
황색의 용종상 종물이 좌측 비중격 후벽부에서 기시하였으 며, 약 $1 \mathrm{~cm}$ 정도의 기저부는 하방의 골막과 잘 분리되었 다(Fig. 3). 상비갑개와 중비갑개를 외측으로 편위 시킨 채 사골동과 하비갑개 후반까지 닿아있는 양상을 보였으나, 주변 점막 및 골 침범 소견은 특별히 관찰되지 않았다. 종 물의 경계를 명확히 확보하기 위해 중비갑개 일부를 자르 고, 상비도를 노출시켰다. 종물을 완전히 절제한 뒤 경계 확 보를 위하여 기시부위의 골막과 좌측 중비갑개를 일부 제 거하였다.

술 중 시행한 동결 절편 조직검사상 방추 세포의 분포와 불균등한 세포질의 분포 양상으로 미루어 신경원성 종양 가능성이 제기 되었다. 최종 조직검사에서 S-100 단백 면 역 염색 상 양성 반응으로 신경초종에 합당한 소견을 보였 다(Fig. 4).

환자 현재 술 후 5 개월째로 정기적인 외래 추적 관찰 중 이며, 재발소견 없이 점막은 잘 치유되어 있으며, 다른 증 상은 호소하지 않고 있다(Fig. 5).

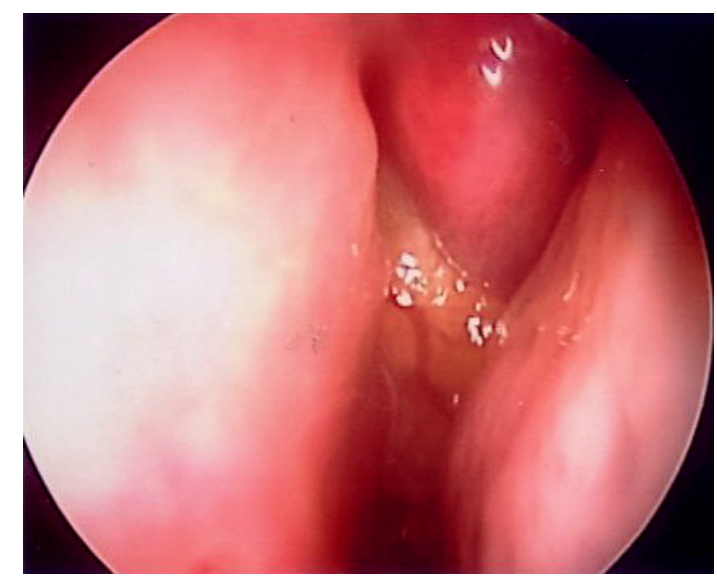

Fig. 1. Endoscopic finding of septal mass. In endoscopic exam, a yellowish polypoid mass is identified at left superior meatus with high vascularity of surface.

\section{고 찰}

신경초종은 말초 신경집의 신경초 세포에서 기원하는 양 성 종양으로, 말이집 신경 (myelinated nerve)이 분포한 곳 이라면 어느 곳이든지 생길 수 있다. Verocay ${ }^{4}$ 가 1908년 처음 보고한 이후 여러 이름으로 불려오다가, 1942년 Del Rio-Hortega에 의해 신경초종으로 불리게 되었다. ${ }^{2)}$ 약 25 45\%의 빈도에서 두경부 영역에 분포하며 주로 제 8번 뇌신경에서 기원하는 청신경종(acoustic neuroma)이 대 부분이다. 특이한 점은 시각 신경과 후각 신경에는 신경초 세포층이 분포하지 않기 때문에 신경초종이 발생하지 않는 다. ${ }^{5)}$ 두경부 영역에서 비강 내에 발생하는 신경초종은 약 $4 \%$ 의 빈도로 드문데 주로 사골동에서 기원하는 경우가 많다. 이중 비중격 내에서 기원하는 경우는 극히 드물어 전 세계 적으로 지금까지 20예 정도만이 보고되었다. ${ }^{6)}$

국내 문헌에서 비강 내 기원한 신경 초종은 비전정 (nasal vestibule)에서 기원한 경우 1 예, ${ }^{7)}$ 사상판(cribriform plate)

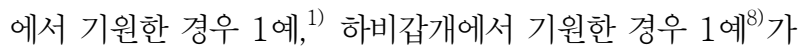
각각 보고된 바 있다.

임상적으로 증상은 종물의 분포나 지배 신경의 기원에 따

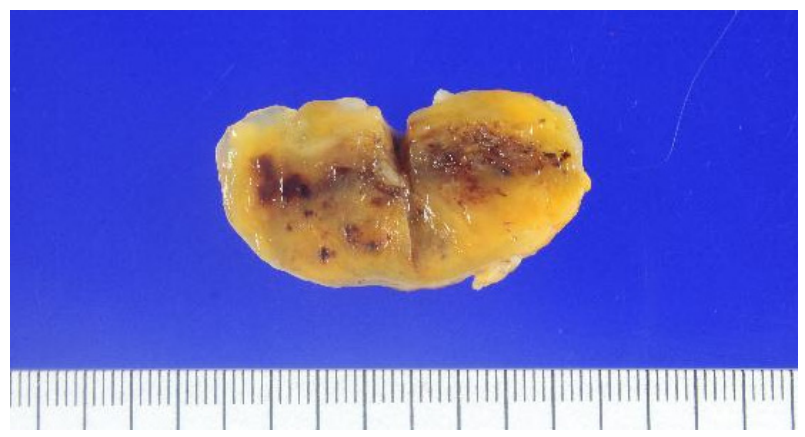

Fig. 3. Gross feature of specimen. Figure shows a $38 \times 20 \times 15$ $\mathrm{mm}$ sized mass. Cut surface of the specimen reveals yellowish well capsulated lesion which containing grayish myxoid stoma.

Fig. 2. Paranasal sinus enhanced CT scan of axial (A) and coronal (B) view. A $36 \times 18 \mathrm{~mm}$ sized large lobular mass with inhomogeneous contrast enhancement involving the left nasal cavity, left ethmoid sinus.
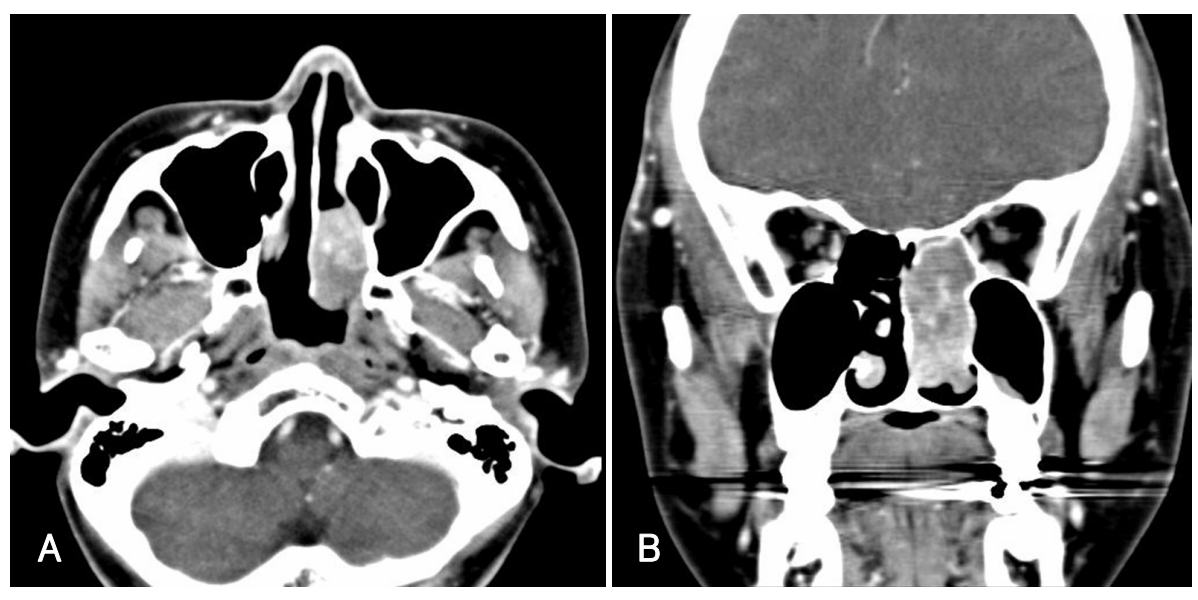
Fig. 4. Pathologic findings of specimen. Light microscopic appearance of tumor shows proliferation of many spindle cells with whorling pattern (Hematoxylin \& Eosin stain, $\times 200$ ) (A). Immunohistochemical staining reveals positive reaction for $\mathrm{S}-100$ protein (S-100 stain, $\times 200)(B)$.
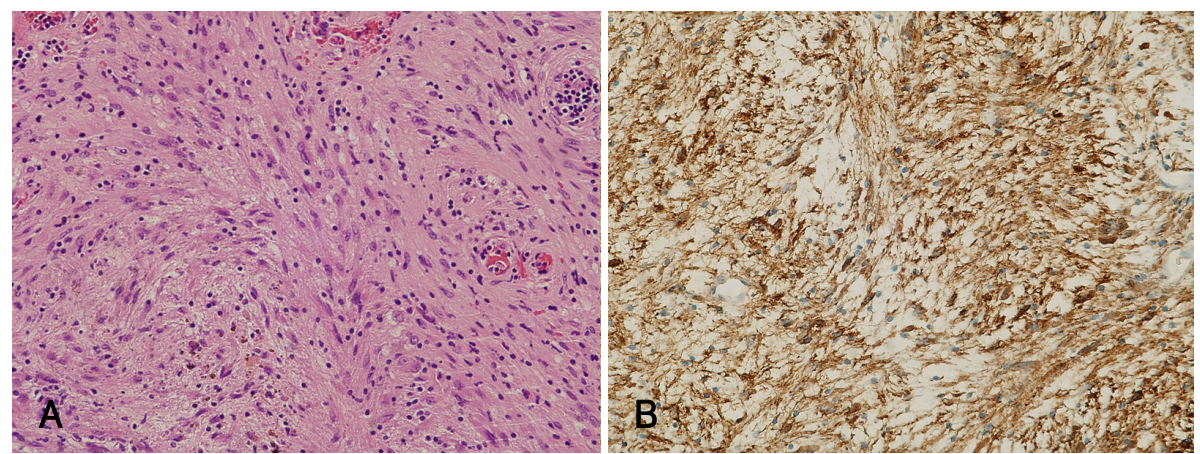

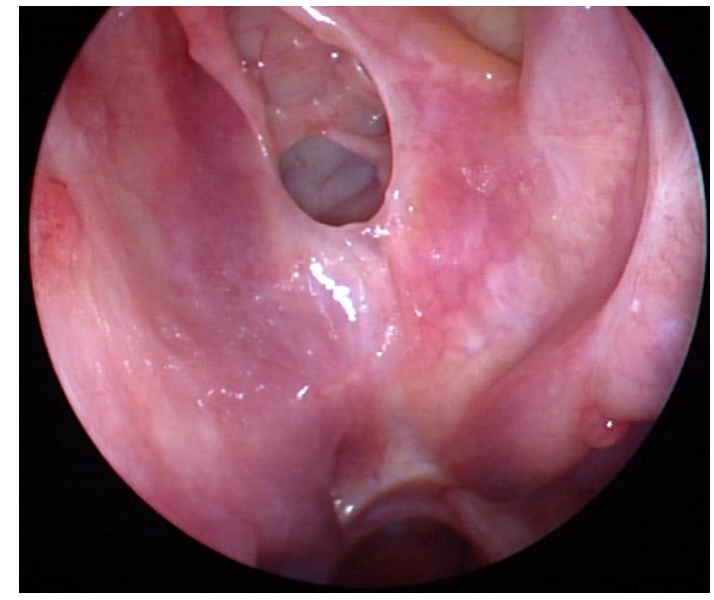

Fig. 5. Post-operative endoscopic finding at postoperative 5 month Figure shows well healed state of mucosa over nasal septum.

라 다양하지만, 주로 종물에 의한 압박감 혹은 통증, 비폐 색, 비루, 후각 이상 등을 호소할 수 있으며, 본 증례의 경 우 환자는 편측의 비폐색, 재채기, 비루가 주증상으로, 비 폐색과 동반된 비염 증상 외에 특이 증상은 없었다.

이학적 검사상 피막에 잘 싸여진 점액질 혹은 낭성의 비 특이적인 용종상의 종물로 관찰되며 이는 일반적인 비강 내 용종 및 혈관성 종물, 혹은 흑색종 및 후각 신경모세포 종과 같은 종양과 감별이 쉽지 않다. ${ }^{2}$ 본 증례에서도 비 내 시경을 통한 이학적 검사상 고혈관성 용종 양상으로 혈관 성 종물을 먼저 의심하여 술 전 혈관 조영술 및 색전술을 고려하게 되었다.

신경초종의 방사선학적인 소견으로는 조영 증강 컴퓨터 단층 촬영상 종물 내 주변 낭성 조직과 구분되는 부분적인 고밀도의 조영증강을 보이는 것이 특징이며, 자기 공명 영 상 촬영상 $\mathrm{T} 1$ 에서 중등도의 신호, $\mathrm{T} 2$ 에서 다양한 신호 강 도를 보이는 것이 특징이다. ${ }^{3)}$

본 증례에서도 이상의 이학적 소견 및 방사선학적 소견 은 비특이적으로 확진을 위한 조직학적 절제 및 생검이 요 구되었다.
신경초종은 병리학적으로 두 가지 특징소견을 보이는데 Antoni type A와 B로 구분되며, 임상적으로는 대부분 두 가지 형태가 혼재된 양상을 보인다. Antoni A형은 고밀도 의 방추형세포가 주위 결합조직과 잘 배열이 되어 있고, 핵 은 책상 배열(palisading pattern)을 이루며 내부에 Verocay body 분포를 특징으로 한다. 이에 비해 Antoni B형은 상대적으로 퇴행성의 변화와 함께 엉성한 점액질의 간질 조 직 분포를 보이며 간혹 출혈성 괴사를 동반하기도 한다. 또 한 신경초종은 S-100 단백 면역 화학 염색의 양성을 보이 는 것이 특징적이다. S-100 단백질은 신경관(neural crest) 에 특이적인 표지자로서, 편측 비강에 생기는 종양 중 S100 단백질에 음성 반응을 보이는 유년기성 비인두 맥관 섬유종(juvenile angiofibroma), 고립성 섬유종(solitary fibrous tumor), 선천성 혈관외피 세포종(hemangiopericytoma) 등과 신경초종의 감별에 유용하게 사용될 수 있다.5)

신경초종은 방사선 치료에 저항성이 있으며 외과적 적출 을 원칙으로 한다. 대부분 신경초종이 주변 구조물과 구분 이 잘되고 조직학적으로 양성이기 때문에 비내시경적 접근 에 의한 제거로도 충분하다고 알려져 있으나, 종물의 위치 나 크기에 따라 외부적 접근이 필요한 경우도 있다. ${ }^{2,5,9)}$ 악 성 변화가 거의 없고 재발은 드문 편으로 알려져 있다. ${ }^{9,10)}$ 본 증례에서도 주위 조직에 침윤하지 않고 잘 분리되는 양 상으로 비내시경적 접근으로 충분히 절제되었다.

비중격 내 발생한 신경초종의 경우 임상 증상 및 이학적 소견만으로는 다른 질환과 감별 진단이 쉽지 않기 때문에 주의를 요하며, 병리 조직학적 검사와 함께 특이적 단백 면역 염색을 통해 진단하는 것이 중요하다.

\section{REFERENCES}

1) Choe H, Jun YJ, Cho WS, Kim TH. A case of schwannoma of the nasal cavity mimicking olfactory neuroblastoma. Korean J OtolaryngolHead Neck Surg 2007;50 (6) :548-51.

2) Berlucchi M, Piazza C, Blanzuoli L, Battaglia G, Nicolai P. Schwannoma of the nasal septum: a case report with review of the literature. Eur Arch Otorhinolaryngol 2000;257 (7):402-5. 
3) Rajagopal S, Kaushik V, Irion K, Herd ME, Bhatnagar RK. Schwannoma of the nasal septum. Br J Radiol 2006;79 (943) :e16-8.

4) Verocay J. Zur kenntnis der 'Neurofibrome' Beitr. Path Anat 1910;48: $1-68$.

5) Wang LF, Tai CF, Chai CY, Ho KY, Kuo WR. Schwannoma of the nasal septum: a case report. Kaohsiung J Med Sci 2004;20 (3):142-5.

6) Tidmore T, Calhoun KH, Hirschi S, Miick R. Columellar schwannoma Ear Nose Throat J 2009;88 (10) :E38-40.

7) Boo SH, Hong JW, Heo MJ. A case of neurilemmoma in the nasal vestibule. J Rhinol 2008;15(2):140-3.

8) Park SY, Han WJ, Kim MS, Noh KK A case of schwannoma in the nasal cavity. J Clinical Otolaryngol 2006;17 (2):253-6.

9) Cakmak O, Yavuz H, Yucel T. Nasal and paranasal sinus schwannomas. Eur Arch Otorhinolaryngol 2003;260 (4):195-7.

10) Wada A, Matsuda H, Matsuoka K, Kawano T, Furukawa S, Tsukuda M. A case of schwannoma on the nasal septum. Auris Nasus Larynx 2001;28(2):173-5 